\title{
DEMOCRATIC SPACES IN THE MAKING? PROFESSIONAL ASSOCIATIONS AND CORRUPTION IN 2003
}

A member of the Institution shall at all times put the interests of the community and public above those of the individual.

A member of the Institution shall act so as to uphold and enhance the honour, dignity, integrity, standing and reputation of the profession.

A member of the Institution shall not indulge in any corrupt practices. ${ }^{1}$

1. Background: From the 'Politics of Integrity' (Julius Nyerere 1962-1985) to the 'Politics of Shamelessness' (Ali Hassan Mwinyi 1985-1995)

Until the 1980s, Tanzania was renowned to be a country with a remarkable sense of public ethics. ${ }^{2}$ Under the charismatic founding father of Tanzania, Julius Nyerere, integrity was held to be a core virtue of society, and consequently corruption was harshly condemned, particularly when practised by holders of political or public officials. Nyerere held very strong convictions on the corrupting influence of wealth on political office, to the extent that an explicit choice had to be made between economic wealth and political power. "I believe myself that corruption in a country should be treated almost in the same way as treason. If people feel that justice can be bought, what hope are we leaving with the people?"4 However, the nationalisation of the economy under the flag of

1 See the Constitution of the Institution of Engineers Tanzania (IET 2001: 15, Sections 8.02-8.04), one of the key professional associations of engineers.

2 The facts in this section, when not quoted otherwise, are drawn from following documents: Fischer 2006, Bigsten/Danielson 2001, World Bank 2000b, as well as drawing on the sources of the field research in January and February 2003.

${ }^{3}$ In 1967, Tanzania (already de facto a one-party-state) became a Socialist state under the Arusha Declaration, which decreed the nationalisation of the private economy and the media. Subsequently over 400 parastatals were created; supplemented by the Leadership Code of 1972, public officials and politicians were prohibited to own shares in private enterprises or undertake commercial activities of their own (for accounts from different perspectives see, most notably, Iliffe 1979 and Hyden 1980).

4 Nyerere on May 17, 1962 at the 35th Session of the Legislature, cited in Bakari 1996: 55 . 
African socialism and self-reliance ${ }^{5}$ provided a multitude of opportunities for corruption. In particular the discretionary and monopolistic powers of the national party TANU and its successor $\mathrm{CCM},{ }^{6}$ the parastatal enterprises and the public officials within the administration lead to text-book rent-seeking and extortionary behaviour, exacerbated by very low salary levels and harsh economic conditions. These practices were endemic, but kept in check by the personal integrity and frugality of the President and his charismatic authority, so that neither he himself nor his government were tainted by a corrupt image-unlike the conventional wisdom on strong African leaders and one-party-states. Whilst the ever growing and unwieldy public sector certainly did create opportunities for corrupt enrichment and extortion, the political leaders were extolled. This may be partly an example of how leadership can make a positive impact on political culture. ${ }^{7}$ However, it cannot be denied that the check on corruption was also a product of a starved economy; the opportunities for discretionary practices by public officials were abundant, but the means and the spoils were very limited. ${ }^{8}$

However, Nyerere's increasingly authoritarian rule and what turned out to be disastrous economic policies came to a head with macro-economic bankruptcy looming in the 1980s. Nyerere himself laid the groundwork for a line of escape by negotiating controlled liberalisation strategies with the IMF and the World Bank in the mid-eighties; he also prepared his exit from political centre-stage by appointing his successor. In 1983, the revered and respected Julius Nyerere handed over the presidency to Ali Hassan Mwinyi. Under the second president of the Republic of Tanzania, the whole political and economic context changed dramatically. Liberalisation strategies had already seeped into the centrally planned economy under Nyerere, but the new government pursued the full introduction of the market economy. Moreover, the long-called for transition from a

5 See Hauck 2001: 201-10, Hyden 1980, or Jennings 2003 for detailed analyses of the post-Arusha period of Ujamaa.

6 The acronyms stand for Tanganyka African National Union, which was later renamed to Chama Cha Mapinduza (i.e. Revolutionary Party). Nyerere, the founding father and leader of TANU, remained party chairman of the CCM until 1990, seven years after leaving office.

7 On this point, see Bratton/van der Walle 1997 on leadership and political systems in Africa; Gros 1998 on the impact of Nyerere's leadership on democratisation in Tanzania; and Rotberg 2009 on corruption and leadership in general.

8 To my knowledge, there are no surveys on corruption available for this period; this observation is based on personal communication by interviewees and relevant information found in the literature (e.g. Gros 1998; Warioba Report 1996). 
socialist country to a full multi-party democracy was also initiated with Nyerere's blessing, resulting in the amendment of the Constitution in 1992 and the first transition elections in 1995. In fact, corruption may have been the prime factor for swaying the immense-if unofficial-influence of Nyerere in support of multi-party democratisation, undoing his life-long endeavour for single party democracy. In an inquiry into the causes of Nyerere's change of heart, Gros comes to an interesting conclusion:

The ruling party had become too corrupt for Nyerere to morally justify its monopoly. Nyerere admitted as much when he remarked in February of 1995 that 'Tanzania stinks with corruption'. ${ }^{9}$ [...] As long as the party was not subject to competition, acts of corruption could be expected to occur and go unpunished. What motivation did CCM officials have to clean up their acts, if they did not have to worry about losing power? For Nyerere, multipartyism became the disinfecting solution which would permit CCM to reconnect with the people (Gros 1998: 103).

Whatever Nyerere's personal reasons were, the radical and fundamental transformation of the institutional framework informing the political and economic order in Tanzania did not result in the generally aspired breakthrough in standards of living. On the contrary, it created huge institutional insecurity which provided many opportunities to those in power to interpret and shape the rules of the game according to their own private interest. ${ }^{10}$

In other words, it seemed as if after decades of politics of ascetism and economic hardship the flood-gates of wholesale, unsanctioned and even socially accepted enrichment had been thrown open. The privatisation of state-owned and parastatal enterprises regulated (in the loosest sense of the word) by inexperienced and untrained officials and inappropriate, dysfunctional or disbanded institutions - from the legal framework to the financial institutions - provided an open field for the systematic plundering of national resources as well as the unheard of amounts of incoming FDI. Land-grabbing, massive investment scams, exponentially growing kick-backs, commissions and outright bribes for the granting of contracts and licences, large-scale tax evasion right down to the selfserving interpretation of the law and the corruption of judges and lawyers

9 The Guardian, 11 February 1995, cit. in Gros 1998: footnote 24.

10 This is what Cartier-Bresson 2004 terms 'new corruption' deriving from structural transformations and changed opportunities, as opposed to the (neo-)patrimonial, rentseeking 'old corruption'. 
became the order of the day. ${ }^{11}$ By the end of Mwinyi's tenure, corruption had become a way of life, "so much that public officials are not ashamed to either demand or receive bribes. In fact, officials consider it right and the public consider it an obligation to offer bribes in order to be served" (The United Republic of Tanzania 1996b: 3), as a Former Foreign Minister described "this shameless proliferation of bribery and corruption" (The United Republic of Tanzania 1996b: 3).

\section{Benjamin Mkapa (1995-2005)—'Zero-Tolerance of Corruption'}

When Benjamin Mkapa was elected president in Tanzania's first multiparty elections in 1995, he found himself leading a country which within a mere decade had undergone a complete metamorphosis, both in terms of political ideology as well as institutional structure. The problems generated by the rapid structural transformations were considerable. For instance, the World Bank concluded in its surprisingly candid Country Assistance Evaluation of the year 2000 that

the review of economic developments in Tanzania through 1995 and the efficacy of the Bank's assistance efforts suggests a decidedly mixed outcome on many counts. The development issues facing the country by 1996 were many and severe, ranging from low growth and macro-instability, to pervasive poverty, a poor enabling environment for private enterprise, inadequate domestic ownership and weak donor coordination (World Bank 200oc: 8).

Faced with these severe developmental challenges in a context where corruption had become the norm, not the exception, Mkapa turned the fight against corruption into his ticket for government. Just before his election, he published his political priorities in a pamphlet with the title 'Building a Vision'. Mkapa's very first sentence addresses corruption, ${ }^{12}$ and he elaborates his view of the problem in a section wholly dedicated to corruption:

11 See the Warioba Report 1996 for detailed evidence.

12 The first question and first sentence of Mkapa's answer on the first page of the document is as follows:

Q: You have been elected Tanzania's third post independence President. What were the main issues and concerns that were raised in (a) rural areas and (b) urban areas, during the campaign?

A: Corruption was a big issue and I addressed it before it was even raised (Mkapa 1995: 1). 
Q [David Martin]: The foreign media, indeed your local media, have said that corruption was the main issue of the election which was about electing a 'Mr Clean'. Was this true and what exactly do people mean when they talk about corruption in Tanzania?

A [Benjamin Mkapa]: Corruption featured immensely. I raised the issue at all my meetings. There is a widespread feeling among the population, as well as in the donor community, that it's a serious disease in our society, it's an impediment to justice and fairness, it has reached the point where it is a serious impediment to development.

How is corruption seen here? With the general population, it's a fact that there is a feeling you cannot get anything done without 'a consideration' to the person who is obliged by law, or whom you have asked to carry out their duties. Without a 'consideration' you won't get anything done. I get complaints that policemen can ask for anything from anybody, sometimes even to let you pass some place. That you can't get medical attention without passing something to the nurse or doctor, even, sometimes, the supervisor. You can't get your file in a government ministry if you are trying to get your land registered or whatever. There is a file opened there. Suddenly it disappears and cannot be found again until something has passed on to the registry clerk. You see this is the feeling, this is the perception of corruption in our situation.

But on a larger scale, in terms of Government contracts, tenders, licensing and so on, there is a feeling that favours are granted, proper criteria are put aside and so on. And this is a really serious disease in our society (Mkapa 1995: $5^{-6) .} .^{13}$

In other words, Mkapa showed vocal commitment to eradicating corruption, which began with his political campaign and, after his election, extended to the support of extensive governance policies. He appointed a Presidential Commission on Corruption in 1996 to investigate the state of corruption in Tanzania, and the findings were published in what became

13 However, in the document Mkapa elaborates no concrete steps to prevent corruption in future, apart from renewing the value system and increasing the remuneration package of the civil service (see Mkapa 1995: 6), and set an example by declaring his assets after being sworn in (Mkapa 1995: 8), a promise he kept. However, given the fact that at the time of writing (2009) Mkapa is himself suspected to have illegally enriched himself through the purchase of a mining company at grossly underpriced value (see further down), the following statement rings either deeply cynical or prescient: "Corruption now at the political level is perceived as the use of public office for self-enrichment. You know, I get into a party as a simple person, I become a minister, I retire or am sacked at the end of four years. And suddenly I have become the owner of a large enterprise which could not possibly have been earned by the remuneration which was given to me by virtue of my ministerial office. And the only explanation then is that you used the ministerial authority to influence matters in return for the wealth that you have accumulated" (Mkapa 1995: 6). 
to be known as the Warioba Report. ${ }^{14}$ The report was extremely thorough and forthright in its disclosures, and in its trenchant critique of the state of the nation. The key statement of the report was that "[c]orruption is rampant in all sectors of the economy, public services and politics of the country" (The United Republic of Tanzania 1996a: 476); a claim it substantiated in extensive public hearings. The conclusion drawn on the extent of corruption was that petty corruption is pervasive in most public services and affects the population most directly, with systematic grand corruption identified especially in procurement, the allocation of permits and large public contracts, in particular construction. ${ }^{15}$ In analysing the causes of such widespread corruption, the Warioba Report refused to succumb to the temptation of justifying it in general terms of a 'poor and underdeveloped' country. Instead, the report bluntly addresses the issue of responsibility: "It has become evident that the greatest source of corruption in the country is not the poor economy and low salaries; although these too have played some part. The greatest source is the laxity of leadership in overseeing the implementation of established norms" (The United Republic of Tanzania 1996a: 9). ${ }^{16}$ According to the report, hence, the problem of fighting corruption in Tanzania was not a question of legislation or capacity; the central problem, according to the Commission, was the unwillingness of the government to 'walk the talk', to follow up official policy priorities with implementation and enforcement.

Given the growing sense of disgust with corrupt behaviour and the acutely felt problems that such wasted and embezzled resources meant for the population, the report would have provided the President volatile fuel for instigating blazing reforms of the political order. According to the general perception gleaned from the interviews as well as from the tone of editorials and columns in the national press, the President lacked the "moral courage" (as a former high ranking public official stated in an interview) to capitalise on this unique chance; the named and shamed officials were not prosecuted (apart from one Minister), and the implementation

\footnotetext{
14 See The United Republic of Tanzania 1996a, b. Stephen Riley dryly comments this "remarkable set of events" by pointing out that "very few African governments investigate themselves, although they are very willing to investigate their political opponents" (Riley 1998: 144).

15 According to principle-agent informed economic theories and derived theories of rent-seeking, these sectors classically feature the greatest vulnerability to corruption as a result of the discretion, monopoly and size of potential profits. See Klitgaard 1988, MoodieStuart 1997, or Khan 2000 for extensive analyses.

16 See also Muganda 1997 or Chachage 1996 for an appraisal of the Warioba Report.
} 
of the very concrete recommendations got bogged down in bureaucratic manoeuvres. In other words, the report-with three of the most incriminating pages missing — was de facto shelved. ${ }^{17}$

Still, under President Mkapa, there was a comprehensive range of governance and corruption policies designed and implemented, embedded in a National Framework on Good Governance. They include a National Anti-corruption Strategy and Anti-corruption Plan (NACSAP), the reinforcement of the Prevention of Corruption Bureau, the establishment of the Good Governance Coordination Unit, and legal reforms such as the Public Leadership Code of Ethics (2001) and the Law on Combating Corruption (2003, amended 2007). ${ }^{18}$ In the following section, an overview shall be provided over the most important of existing and newly established governance policies in Tanzania in the year 2003.

\section{Regulatory Framework and Anti-Corruption Institutions}

\subsection{Prevention of Corruption Act (PPA)}

The PCA dates back to the Prevention of Corruption Act, No 16 in 1971. This Act was amended in 2002 to bring it in line with international standards. However, it was criticised for being flawed as a result of a very limited definition of corrupt practices and inconsistent provisions (see the following chapter for a more comprehensive discussion).

\subsection{Prevention of Corruption Bureau $(P C B)$}

The PCB ${ }^{19}$ dates back to 1974, when an Anti-corruption Squad was established under Act No 2. In 1991, the Squad was restructured and renamed the Prevention of Corruption Bureau (PCB), established under the President's Office. Appointments are made by the President. The tasks of the PCB are to investigate, educate and advise the government on cases of corruption. Prosecutions of public officials need the prior consent of the Director of Public Prosecutions. The PCB has a head office in Dar es Salaam and 43 district offices. Between 2000 and mid-2004, the PCB investigated 9507

\footnotetext{
17 See Fischer 2006 for detailed evidence.

18 For a detailed discussion on the history and design of Tanzania's anti-corruption policies see Hussman/Mmuya 2007.

19 The information in this section is based on the website of the PCB, on the Business Anti-corruption Portal, and on Doig et al. 2005.
} 
cases (out of 10'319 received), of which 357 were prosecuted, resulting in 48 convictions. Challenges of the PCB are lack of resources and perceived lack of independence from the President's Office. In spite of these challenges, it is the leading anti-corruption institution in Tanzania.

\subsection{Commission for Human Rights and Good Governance (CHRGG) (2001)}

The CHRGG was established in 2001. It acts as an Ombudsman office to investigate complaints of administrative justice, in particular relating to human rights abuse and abuse of power. It can make recommendations to the government. However, in practice the CHRGG has very little public visibility.

\subsection{The Good Governance Coordination Unit (GGCU) (2001)}

The GGCU ${ }^{20}$ is located in the President's Office, and formally mandated to monitor, coordinate, evaluate and report on the implementation of the NACSAP across all MDAs. The President also appointed a Minister of State (Minister of Good Governance) to supervise good governance issues. Like the CHRGG, the GGCU is severely understaffed, and acts in strong cooperation with the PCB. ${ }^{21}$

\subsection{The Public Service Ethics Secretariat}

The Public Leadership Code of Ethics Act of 1995 requires public leaders to declare and register their assets in the relevant register managed and overseen by the Public Service Ethics Secretariat. However, the annual reports of asset declarations are only accessible under very restrained conditions. In practice, few Government officials do declare their assets, ${ }^{22}$ although in 1996 President Mkapa lead by example by publicly declaring his assets.

20 See the official website http://www.chragg.go.tz/.

21 According to the Country Procurement Assessment Tanzania (World Bank 2003a: 79, para. 181), the GGCU issued a report in 2002, which includes a series of indicators for monitoring public procurement (developed jointly with the World Bank). However, no further information could be found and, as far as could be assessed, these indicators were not yet operational.

22 See for instance the "Government officials flout Ethics law as corruption becomes rife and hefty" on the Tanzania Corruption Tracker Website (see http://www.corruptiontracker.or.tz/index.php?option=com_content\&task=view\&id=47\&Itemid=29; last accessed 2 March 2010). 


\subsection{National Anti-Corruption Strategy and Action Plan (NACSAP)}

Based on the 'zero-tolerance-principle' towards corruption, the government of Tanzania developed a comprehensive National Anti-Corruption Strategy and Action Plan (NACSAP) in 1999, implemented from 20012006. NACSAP's objective is to address and streamline key anti-corruption reforms in the public sector, drawing on sector strategies put together by government institutions. The Strategy, a slim booklet of 29 pages, analyses and prioritises areas of action, identifies supporting processes, and finally draws up a detailed implementation plan. The following excerpt charts the comprehensive targets set by NACSAP:

This strategy, therefore, outlines short term and long term national objectives. It addresses prevention, enforcement, public awareness and institution building $[\ldots]$.

Specifically, this strategy will lead to the achievement of the following:

- Increasing respect for the Rule of Law, enhancement of good governance and promotion of ethical leadership within its ranks and agencies.

- Strengthening the judicial system so that justice is neither sold nor bought.

- Having Protection Programmes for co-operative witnesses and whistleblowers.

- Transparency in government and tendering and procurement contracts.

- An effective and friendly immigration agency, ports, customs and excise services.

- A Government that has zero-tolerance for corruption.

- Building, promoting and safe-guarding a culture of self-reliance and collective responsibility in the fight against corruption.

- Reinforcing the policy and sharpening the legal framework that will prevent corruption.

- Strengthening the law enforcement agencies, namely, the Prevention of Corruption Bureau, the Police, the Ethics Secretariat and the Permanent Commission of Enquiry.

- Promoting the interface between Civil Society and the Government in a partnership to fight corruption.

- Inculcating in society the belief that transparency, integrity and accountability are virtues of good government and necessary bulwarks against corruption. ${ }^{23}$

23 The United Republic of Tanzania 1999: 6-7. 
These objectives reflect the recognition that the control of corruption is more than just a question of the right legal framework, law enforcement or public institutions. It recognises that especially in a under-resourced country, undergoing the rapid and fundamental structural changes witnessed by Tanzania in the past decade, anti-corruption efforts require a many-layered approach. Operationally, therefore, the reforms are targeted in seven, mutually enhancing priority areas:

- rule of law and legal framework

- financial discipline and management

- procurement

- public education, awareness and sensitization of their rights

- public service reform

- whistle blowers and witness protection

- media $^{24}$

The implementation of NACSAP is primarily the responsibility of the national Ministries, Departments and Agencies (MDAs) themselves. They were required to report their progress through quarterly self-assessment reports to the President, via the GGCU. ${ }^{25}$ De facto the PCB manages the implementation of NACSAP, although de iure the GGCU is responsible for the coordination and monitoring of NACSAP's implementation.

However, as mentioned above, the GGCU is severely constrained by its narrow mandate, limited to the collection and publication of the self-assessments, as well as its lack of staff and leadership. The reporting system suffers from further weaknesses. In particular, it is limited to reporting corruption cases, but not on reforms in management systems or procedures. Also, external assessments are not included, for instance by citizens and 'users'. ${ }^{26}$ Apart from monitoring weaknesses, a key problem of NACSAP was its confinement to central government institutions, excluding highly corruption-prone areas such as Local Government Authorities. Also, the role of civil society and the private sector in supporting the government in its anti-corruption efforts was underdefined. Lastly, and not surprisingly, the implementation of NACSAP suffered from a severe lack of human resources, both on the coordination and supervision level, as well as within the Ministries, Departments and Agencies themselves.

\footnotetext{
24 The United Republic of Tanzania 1999: 10.

25 See www.repoa.or.tz/tgn/tgn.php for information on the quarterly self-assessment reports; for a synthesis of reforms see The United Republic of Tanzania 2006: 1-26.

${ }^{26}$ For a detailed assessment of the implementation of NACSAP see Hussman/Mmuya 2007: 187-190.
} 


\subsection{Governance Reforms under Mkapa: An Assessment}

In sum, it can be seen that extensive governance reforms were undertaken under the auspices of NACSAP, in particular legislative reforms, such as the Public Procurement Act or the amendment of the Prevention of Corruption Act. No doubt that NACSAP also served to create a greater public awareness and underline the political priority of anti-corruption reforms. However, the much-heralded fight against corruption has not lead to significant results. One factor impeding its implementation that cannot be stressed enough, namely that the objectives, ambitious under any circumstance, were sought in a context of financially, technically and organisationally under-resourced institutions; also, the oversight and regulatory institutions tasked with institutionalising the reforms are completely new or fundamentally restructured. In other words, key institutions were themselves undergoing major reforms while at the same time required to perform sophisticated roles and functions. ${ }^{27}$

A second key factor are the multiple articulations of political will in the public sphere, manifested in a plethora of manifestos and policies, but at the same time conspicuous in its absence with regard to concrete measures. Interestingly, within NACSAP the importance of political will to achieve the challenging objectives is spelled out explicitly. ${ }^{28}$ The imploration of political will as a sort of a deus ex machina is telling, if evidently neither horizontal accountability institutions nor social and political actors are in a position to keep the government's performance in line with its promises and policies.

This takes us to the third factor. Given the far-reaching social, political and economic implications of NACSAP, it is surprising to note that the anti-corruption policies have been nearly entirely state and donor driven, with hardly any pressure coming from civil society. Although it may be assumed that citizens bear the double brunt of corruption, by paying for public services and suffering from wasted public resources at the same time, a fatalistic or even accepting attitude towards corruption seems

27 The overburdening of underresourced institutions and agencies was witnessed in various public agencies during the research for this case-study on the construction industry. For an astute analysis highlighting precisely this aspect in Tanzania's public sector reform see Therkildsen 2000.

28 "Political Will refers to demonstrated intent of political actors such as is the case here in Tanzania to attack perceived causes and effects of corruption at a systemic level. This corruption refers to an environment that involves the bureaucratic elite, politicians, businessmen and workers in embezzling public money at a large scale through various means" (The United Republic of Tanzania 1999: 9). 
to prevail. This apathy is partly a function of the virtual absence of civil society organisations that are not in some way tied to the state. Tellingly, for instance, in 2003 the Tanzanian chapter of Transparency International was all but dysfunctional. The only civil society organisation explicitly addressing corruption was FACEIT, which co-authored the Annual Report on Corruption in Tanzania 2001. Other organisations addressing corruption only did so through their own focal activities, such as education or human rights. ${ }^{29}$

The absence of strong civil society organisations is generally acknowledged..$^{30}$ In the case of corruption, civic apathy also seems to be a result of a general disenchantment and loss of confidence with the present government's anti-corruption policies. For although the fight against corruption still ranks high on the government's rhetorical agenda, the political will to effectively sanction illegal, corrupt practices committed by public officials and effectively implement and institutionalise reforms was not evident. The stir and sense of a new start caused by the Warioba Commission's Report was not grasped, and the moment of setting examples instigating the necessary fundamental change passed without effect. ${ }^{31}$ Although corruption and the problems it causes were openly talked about, corrupt

29 Examples of two of the most profiled NGOs would be HakiElimu with regard to education (see under https://www.hakielimu.org), or the Human Rights Commission (HRC) with regard to human rights.

30 Consider this excerpt from a Tanzania self-assessment report for Nepad's African Peer Review Mechanism (APRM), authored by an official of the Tanzanian Trade Union Council (TUCTA), under the section 'Governance': "The political and economic transition to a culture of decentralized multiparty democracy, after 30 years of highly centralized one party socialist system is in early stage [sic] [...]. Although there exist a large number of union cooperatives, women and youth organizations, ethnic self-help associations and religious organizations, civil society organizations are not geared to an advocacy role nor is it structured to manage funds or implement large scale programmes. NGOs are weak in terms of legal, financial and human resources and many are directly dependent on international support. Democratization has lead to stronger human rights issues and Tanzania has ratified most important conventions and rules of human rights, however, traditional and national laws combined with local customs and practices still restrict the rights of vulnerable groups in society [...] corruption is widespread phenomenon [sic] in Tanzania hampering development in all segments of society" (Kaaya, undated, but no earlier than 2003: 3).

31 The importance of political opportunities and timing is illustrated by many cases, most notably in Hong Kong. The power of public support to instigate radical change can be witnessed in Kenya after the January 2003 elections. Against all odds, a new government was elected, petty corruption disappeared nearly overnight, and grand corruption is being tackled head-on. The questions, as ever, is how long such enthusiasm and concerted action can last, once every-day problems have set in, political priorities shift, and the accused individuals and threatened actors have had time to organise themselves. 
practices remained deeply entrenched in political and administrative processes. Even the central institution devised to tackle corruption, the Prevention of Corruption Bureau, can boast of no significant record of success. Located within the President's office and with only limited powers to prosecute, the current set-up of the PCB was evidently not conducive to generating results that would bolster the public's confidence in its independence and effectiveness.

Just how implicated the higher echelons of government and public administration was, is illustrated by following assessment of the Business Times of Tanzania:

It is no secret that senior officials who are at the receiving end of graft reports from the public are also invariably on the receiving end of bribes, either through their junior officers, or directly from bribe givers. No wonder no serious action is ever taken against the juniors by the seniors.

The level to which corruption has come in Tanzania requires that the scourge must be tackled from top-down, and not the other way round. If heads of departments and other government institutions want it with a will today-and are unstintingly given the moral and actual support by those above them right up to the highest levels - then corruption would be effectively cut in half tomorrow. ${ }^{32}$

Although the President himself at the time was untarnished by accusations of corrupt behaviour, most of his colleagues in the ruling party CCM were tainted. These rumours erupted in a political scandal in February 2003 when former MP Dr Hassy Kitine raised strong allegations against most government leaders. The evidence suggested that there was more than a hint of truth to his allegations. The president himself was smooth in his reactions to a matter that conceivably could have given him the opportunity to cleanse his cabinet. His response was to withhold bold judgement and demand more evidence:

President Mkapa, who is also the CCM national chairman, said he would personally like to see corruption suspects being prosecuted for the crime and that once their offences are proved beyond reasonable doubt they should be punished without leniency.

'But how can we do so if we don't have the evidence? Ours is a country that adheres to the rule of law,' he said, adding that all suspects should remain innocent unless they are proved to be guilty. ${ }^{33}$

32 "Tackle graft head-on, not via fattened remunerative sops" in Business Times, Friday, 7 February 2003, p. 2.

33 "Mkapa wants proof on graft" in Daily News, Monday, 3 February 2003, p. 1. 
The continual reference to the rule of law by politicians and others in the public discourse on corruption was very notable. This image was reflected and articulated in multifaceted ways and places, in spite of a deep understanding by citizens of the actual practices that were institutionalised within the justice system, ${ }^{34}$ and despite relatively overt official practices running counter to the core principles of the rule of law. For example, the elections in October 2000 were seriously flawed in Zanzibar, and the subsequent riots were violently quashed by the government, resulting in several deaths, an un-apologetic government and international outcry. ${ }^{35}$ According to many interviewees, a less overt practice of the ruling party CCM was to maintain an increasingly firm grip over all key positions in the public sector. This power was used to control the access to political and economic resources, thereby wielding the potential careers and prospects of individuals as a very effective tool in the fight to toe the government's line. Members of opposition parties were systematically barred from any kind of true political power, and vocal dissident voices are quashed by such effective means as regular harassments by the Tax Revenue Authorities, the prevention of re-appointments in public institutions, or the de facto exclusion from public tenders.

Although the political climate in Tanzania was not overtly repressive, the reforms aimed at democratisation did not achieve their substantive objective. De jure, in 2003 Tanzania was not a one-party state anymore, but de facto it remained authoritarian, although the nature of authoritarianism had changed. ${ }^{36}$ Whereas in Nyerere's era it was ideologically and institutionally underpinned, the shifts in the political and economic landscape led to a situation where democratisation and liberalisation were implemented on the surface. However, underneath this formally liberalised surface, the grip of the party was as firmly entrenched as ever. Political monopolisation and public offices as means to certain wealth were a strong deterrent to a genuine democratisation of state and society. This political system was firmly embedded in a culture of ingrained dominance

34 See the findings from the Lawyers Workshop in the State of Corruption Report in Tanzania 2001 (ESRF/FACEIT 2001). This impression was also consistently confirmed in the interviews with all lawyers, engineers, constructors, architects, researchers and journalists.

35 See Amnesty International 2000. "Tanzania-A Human Rights Brief for Election Observers. October 200o". AI Index AFR 56/13 /oo; or the U.S. State Department's “Country Report on Human Rights Practices: Tanzania 2000", Bureau of Democracy, Human Rights, and Labor (23 February 2001), available under http://www.state.gov/g/drl/rls/hrrpt/200o/ af $/ 839 . h$ tm (last accessed 28 October 2009).

36 For a detailed analysis confirming this assessment see Skinlo 2007 (especially Chapter 5). 
of the state over society, and the ideology of unity. It was evident that true public debates between opposing views and interests or between differing factions were very rare and viewed with suspicion. Disputes or challenges between the public, the private sector and/or (more rarely) civil society were routinely addressed by a system of social compacts, a mechanism of gathering all parties together, be it in form of a roundtable, workshop, or the establishment of a commission. Although this political culture explicitly and implicitly referred to the ideology of consensual, integrated politics of African Socialism, it was more likely a rhetorical devie to prevent truly competitive politics. Many of these social compacts acted in an advisory function to the government, but were not endowed with any actual decision-making power. Although the political and economic arenas had opened up, concomitantly the establishment-as crystallised by the members of the ruling party (CCM) - had appropriated these new and lucrative spaces and effectively entrenched their control.

Questioned on the impact of the pluralisation of political institutions in an interview, ${ }^{37}$ an advocate harshly condemned the 'sham democratisation' that was taking place:

Multi-partyism has actually stifled democracy. The CCM is in control of key positions, and the MPs are nominated by the party, so party discipline is high. The opposition is too weak. Now it is actually risky to support the opposition. Now all professionals and intelligentsia are sucked up by the CCM and the government. Even internal criticism is stifled. Everybody's on the bandwagon, toeing the line.

This systematic appropriation of institutional reforms in the interest of the ruling elite was underlined by a culture of top-down consultation and dialogue with stakeholders. Stemming from the socialist order and enforced by donor-driven demands of popular participation, the Tanzanian government nurtured political debates not as oppositional and fractional conflicts, but in the form of round table discussions and social compacts. This participatory smokescreen simultaneously defuses any critique of authoritarianism. Elaborating her perspective on the current politics and political decision-making processes in Tanzania, a social scientist exclaimed:

Now the new politics are incorporated into the state agenda. Interests can only be defended within the state, there are no other spaces apart from government. Because in reality the government stands for the private sector and civil society. Conflicts are solved 'amicably' — how can that be true?

37 If not referenced otherwise, all the direct quotes in this chapter stem from interviews conducted in January and February 2003 in Dar es Salaam, Tanzania. 
In other words, a sense of democratic deliberation was invoked in name only, whereas these forums or social compacts actually served to whitewash the consolidation of authoritarian decision-making processes.

The key features of the political and administrative system framing politics and anti-corruption reforms, i.e. rhetorics rather than deeds, and increasingly authoritarian ruling party, and culture of appropriation through 'consultative' rather than true deliberative processes also framed the agency of professional associations in the construction industry. In the following sections the case-study zooms into the impact of governance policies on professional associations. Setting the stage, first the main actors, agencies and policies will be briefly introduced, before a qualitative analysis of professional associations and political spaces will be undertaken.

\section{Governance Policies in the Construction Industry}

This section is intended to provide an overview over the actors, the policies and the dynamics of governance policies in the construction industry in 2003. Invariably, the reality of a sector or policy is far more messy and intractable than a static and reductionist snapshot, especially in a context of rapidly changing regulatory framework. Still, this is an attempt to render a more tactile and plastic sense of the institutional topography framing corruption and anti-corruption in the construction industry at the time.

\subsection{Actors and Agencies}

Ministry of Works (MoW): The main state actor in the construction industry was the Ministry of Works, which was responsible for planning and procurement related to the construction and maintenance of the national road network and public buildings. So-called Executive Agencies had been established only very recently, with the objective to increase efficiency and effectiveness in the delivery of the MoW's services. These Agencies, such as buildings (Tanzania Building Agency, est. 2002) or roads (Tanroads, est. 2001) were responsible for managing the planning, construction and/or maintenance of certain public services. They were public entities affiliated to the MoW, but autonomous with regard to funding and planning strategies, thereby considerably reducing the scope for discretion and increasing financial accountability. 
Central Tender Board (CTB): The Central Tender Board, based in the Ministry of Finance, was responsible for the regulation of public procurement practice and for the approval and issue of the tenders. It administered procurement of USD 3 million or higher and reviewed procurement between USD 1 million and USD 3 million. Regional tender boards were responsible for tenders of less than USD 1 million. Problematic was its dual mandate of regulation as well as issuing public tenders, which gave rise to a risk of conflict of interest. However, according to the CPAR (World Bank 2003a), the CTB was generally thought to be relatively corruption-free.

National Construction Council (NCC): The most long-standing and probably most important body of the industry is the National Construction Council (NCC). The NCC was established in 1981 with the task of supporting the development of the local construction industry, whose "performance was poor" (according to their website). ${ }^{38}$ In the eighties, given the socialist policies and nationalised economy of Tanzania, the NCC had hardly any private enterprises and no organised representatives of the private sector as counterparts. It was part of the NCC's mission to initiate the founding of private associations. Although it was formally located within the MoW, it was in fact the principal interface between the private and the public sector as a result of its comprehensive coordinating function and policy work. The NCC's main fields of activity were the following: planning, co-ordination and formulation of strategic interventions; technical advisory services, such as project auditing, general consulting, as well as the publication of arbitration rules and institutionalising dispute settlements; development support services, such as specific training programmes, or spearheading the establishment of a construction industry trust fund; productivity and quality management with the industry; information support system ranging from business publications to statistical data. The range of activities reflects the importance of the NCC for the construction industry. Their approach focused on professional, technical and financial capacity-building. The NCC regarded controlling corruption as one of the key measures to support the construction industry. ${ }^{39}$

Regulatory Boards: The liberalisation of the Tanzanian economy in the eighties called for the establishment of regulatory institutions. But only in 1997 the Architects and Quantitative Surveyors Registration Board

38 See under http://www.ncc.or.tz/index.html (last accessed 21 October 2009).

39 Listed as point 5 (out of five) of the NCC's objectives. For a detailed profile of the NCC and further information see under www.twiga.com|ncc. 
(AQSRB), the Contractors Registration Board (CRB) and the Engineers Registration Board (ERB $)^{40}$ were established to register, regulate and support professionals in the construction industry. These bodies define and ensure professional standards and qualifications for each profession through mandatory registration. Furthermore, they act as counterparts for individual enterprises and professional associations to address challenges and problems in the industry. The registration boards incorporate codes of conduct and anti-corruption clauses in their registration process.

Professional Associations: Professional associations in the construction industry could be divided into two categories: 'first-generation' associations that represent the established professions of engineers, architects, and quantity surveyors, and 'second-generation' associations that represent contractors. The very first association was the Institution of Engineers (IET) (1972), founded on the initiative of Tanzania engineers that had graduated in Nairobi, for at that time Tanzania did not yet offer an own engineering degree. The IET was modelled on the Kenyan Institution of Engineers. Only in 1975 was the first domestic course in Engineering offered at the University of Dar es Salaam. A sign of the gradual opening towards a more liberalised economy, the mid-eighties saw a concentrated effort in establishing organised professional efforts. The governmental forerunner was the establishment of the NCC (see above), under whose wings several key professional associations were founded in a short period of time, such as the Association of Consulting Engineers Tanzania (ACET) (1985), the Architects Association Tanzania (AAT) (1985) or the Tanzanian Institute of Quantitative Surveyors (TIQS) (1985). Apart from their commitment to set professional standards and improve the policy framework in the construction industry, these associations had been engaged in regional and international apex organisations right from the beginning. Together with the IET, they were the main formally organised representatives of professional interests of these 'established' professions in the construction industry. ${ }^{41}$

\footnotetext{
40 For further information see http://www.erb.go.tz/.

41 The 2003 website of the NCC lists a total of eight professional associations (see http:// www.intafrica.com/ncc/services.html; last accessed 25 March 2010), of which six have been included in this case-study. This case-study includes one that is not listed (CATA), as it had only just been established in 2003. The associations not included in this case-study, but mentioned on the website, are the Association of Electrical Contractors Tanzania (AECT), the Association of Valuers and Estate Agents (TIVEA), and the Association of Quantity Surveyors (TIQS). The former two were never mentioned in any of the discussions as relevant actors, and didn't appear in any of the policy-making forums and, as will be seen in the case-study of 2009, were disbanded; the latter was not included for lack of contacts.
} 
Only in the late nineties and early years of the new Millennium did the formerly unregulated and unorganised contractors begin to form as corporations. This was a direct result of the increased liberalisation of the economy and the new demands and competitive pressures exerted on informal professions. In 1997, the Tanzanian Civil Engineering Contractors Association (TACECA) was established; as the name indicates, it is the body incorporating only Civil Engineers. Six years later, in 2003, the Contractors Association of Tanzania (CATA) was founded with the explicit aim to represent all contractors, not merely a specialised sub-section.

\subsection{Governance Policies}

Construction Industry Policy (CIP): Reflecting the novelty of the regulation of the construction industry, it may not be surprising that until very recently, Tanzania's construction industry did not have an overall national policy-framework. This gap was closed by the Construction Industry Policy that was adopted in February $2003 .{ }^{42}$ The prime objective of the CIP is to support and facilitate the capacity and effectiveness of the local construction industry by clearly identifying priority objectives and policy directions.

Overall, the policy sought to achieve two objectives:

1. "Implement policies that are deliberately designed to develop and sustain the local construction industry [...]

2. [Attain] "a comprehensive policy to ensure compliance with the national social and economic development objectives and goals" (The United Republic of Tanzania 2003: 7).

In other words, not only is the importance of construction industry as an integral part of social and economic development recognised, but also the need to actively coordinate and support the local industry:

The goal of the construction industry policy is to develop an internationally competitive industry that will be able to undertake most of the construction projects in Tanzania and export its services and products and ensure value for money to industry clients as well as environmental responsibility in the implementation of construction projects (The United Republic of Tanzania 2003: 3).

42 In fact, one of the very first copies of the officially printed version of the CIP, still in an unpolished A4-format, was handed to the author by the director of the NCC in February 2003 . 
The key targets of the Tanzanian construction industry policy constituted enhancing local capacity, skills and know-how; supporting financial, technical and human resources, and generally increasing the competitiveness of the local construction industry. For our purposes most interesting was the explicit prioritisation of anti-corruption efforts. "Ridding the construction industry of corruption" is listed as one of the ten major challenges (The United Republic of Tanzania 2003: 7), an explicit confirmation that corrupt practices in construction were pervasive. The measures formulated to fight corruption were cross-cutting. It was hoped that by improving the capacity of both the local construction enterprises as well as the public sector, the necessary conditions should be generated for the efficient, transparent and effective implementation and management of construction projects, and thereby the prevention corrupt practices through more accountable mechanisms (The United Republic of Tanzania 2003: 8-11).

Public Procurement Act (PPA): Procurement was identified as one of the seven priority areas in the NACSAP, aiming for: "Strict adherence to and transparent administration of tendering and procurement procedures" (NACSAP 1999: 10). The most important measure to achieve this was the passing of the New Procurement Act and Financial Management in 2001. This was a major step for the construction industry, for the former state of weak, inexistent and even contradictory laws and regulations were fuelling discretion, poor quality work, legal insecurity and manifold corruption. Under pressure from the donor community, the government of Tanzania ploddingly initiated the draft process. The process involved professional associations and selected experts who were invited to voice their opinion. However, the actual drafting and writing of the legislation was entirely in the hands of the government and Ministries. Although civil society actors were routinely consulted, the interviews with participants and representatives of professional associations revealed that hardly any of their suggestions were included in the final draft approved by Parliament. "Why call me to participate? What's the point?" was the bitter exclamation of a chairman of a first-generation association who had invested considerable (unpaid) time and effort in combing through the drafts, commenting the provisions and justifying amendments. This is one example of the image of a social compact that the government seeks to portray a decisionmaking process that involves all stakeholders in seemingly participatory and non-contentious way. In practice, however, the outcome was the glossing over adversarial opinions and interests and the pretence of democratic participation in policy-making by non-state actors, whilst in fact securing the decision-making power of the government. 
The main body of the PPA was derived from international best practices. As the first legislation consolidating and regulating public procurement practices on a national level, it represented an important contribution to sound governance in the construction industry. However, there were some blatant weaknesses. For instance, several key areas are excluded from the scope of the PPA, areas known to be most vulnerable to abuse and embezzlement of public funds. For instance, the act was not applicable to procurement involving military equipment, defence forces, or arms and ammunition (Section 2); equally it does not apply to local government authorities (Section 14), which are renowned for their discretionary use of political power. ${ }^{43}$ Not surprisingly, the State of Corruption in Tanzania Report 2002 concluded that these exclusions "give an impression that the Government is not prepared to expose all corrupt practices, and that it may even overlook certain cases of corruption if it considers them politically sensitive" (ESRF/FACEIT 2002: 119).

The professionals' assessment of the PPA varied significantly, depending on their professional standing. Some labelled it "a disaster", because it systematically discriminates instead of protects local consultants. Nearly all pointed out that the pre-qualifications of large tenders were nearly impossible for local contractors to meet, even for the bigger companies, such as the provisions with regard to credit-lines, turn-over, equipment and experience. Others criticise the bureaucratic attitude and slow procedures of the implementing authorities. At the same time, it was contended that "they will learn". And one respondent, a senior engineer, took the sedate and opaque view by commenting that "it's good to have it in place, it makes people feel comfortable".

\section{Corruption and Professional Associations in the Tanzanian Construction Industry}

\subsection{Impact and Extent of Corruption}

The configuration of the construction industry in Tanzania can only be understood against its historical backdrop. As little as twenty years ago virtually no private sector construction industry beyond very small-scale, informal activities existed. Only in the early eighties the support and

43 See for instance ESRF/FACEIT 2003: 83-88; for a detailed case-study see Fjeldstad/ Semboja 2000 or Fjeldstad 2002. 
development of a local construction industry became part of the political agenda. The state as the main economic player was also the dominant stakeholder in all larger building-projects; the public sector planned, funded and undertook the projects, mostly by mandating foreign consulting and construction firms to undertake more complex work. Until then no local construction companies and only a handful of Tanzanian engineers or architects had existed. The local construction industry, therefore, has to be conceived in terms of a comparatively young and nascent sector, which was still in the process of asserting itself in the national economic and political environment. ${ }^{44}$ It is important to bear in mind that the recent history of a state-run economy and little more than a decade of privatisation shaped the institutional framework of the construction industry, in which the public sector plays the central role, and which is characterised serious national development and capacity problems.

Generally it can be observed that public works and construction is one of the most corruption prone sectors worldwide, both in terms of spread and height of bribery, leading the ranks even before Arms and Defence. ${ }^{45}$ The same holds true for Tanzania. For instance, the Warioba Commission devoted about $10 \%$ of its report just to corruption in the road construction sector (Warioba Report 1996). The State of Corruption Report 2001 estimates that about $25-30 \%$ of the government's procurement budget in Tanzania was lost due to corruption, bribery and fraud. ${ }^{46}$ The impact of this figure can be gleaned from the fact that the procurement of goods, services and works accounts for more than half of the government's entire expenditure budget (Annual Report on the State of Corruption in Tanzania 2001: 125) ${ }^{47}$ As Judge Warioba pointed out at a Workshop on Corruption

\footnotetext{
44 This is underlined by the fact that only in February 2003 the Construction Industry Policy was formally initiated.

45 When it comes to grand corruption, the rule of thumb postulates that the higher the public expenditure, the higher the corruption (Moody-Stuart 1997). This was confirmed in the first business sector survey of Transparency International, the Bribe Payers Index (BPI), where public works contracts and construction ranked first (i.e. with the highest corruption propensity), ahead of arms and defence industry and power. See survey results under Bribe Payers Index at www.transparency.org.

46 This figure is quoted again and again, even on governmental websites. However, it is not necessarily based on sound methodologies, indicating the need for a more solid data base (see for instance HOAP Group (undated), under www.tzdpg.or.tz/uploads/media/ Procurement_Report_Final.pdf; last accessed 25 March 2010), or the CPAR (World Bank 2003a: 67, para. 152).

47 For instance, the Warioba Report analysed 24 completed road projects between 1990-1995 and found that cost increases reached $59 \%$ of the original contracts. Although these increases may also have other causes, such as changed ToRs or unpredicted
} 
Prevention in the Construction Industry in April 2001, the pattern of corruption in the construction industry indicated systematic and deliberate facilitation of corruption on the higher level, and the general acceptance of corrupt practices on all levels (The United Republic of Tanzania 2001: 4), a view underlined by other speakers in the course of the Workshop.

All of the interviewees of this case-study, both in the private and in the public sector, confirmed that in spite of the institutional and legislative reforms corruption in the construction industry is still rampant. Some of the interviewees contended that the PPA itself was not adequate to provide a sound framework for public procurement; others acknowledged that the framework, whilst not perfect, was a significant improvement to the previous situation; others again, whilst not happy with the present situation, pointed out that the institutional changes and reforms were still very new, and would become more effective with a time lag. Everyone, however, underscored that corruption was still an integral part of public procurement. Given the newness of the PPA, this could also be a function of time within which a sound legislative framework facilitates the gradual institutionalisation of a culture of propriety. The interviewed representatives of professional associations, however, were very guarded in their optimism. The distrust of and dependence on public officials, the evidently deeply engrained abuse of public power, and the sense of impunity by public officials in tendering of public procurement still was very dominant. This view is confirmed by the World Bank's Country Procurement Assessment Report (CPAR) (World Bank 2003a), which identified "malpractices in the selection of consultants, appointment of suppliers, pre-qualification of contractors, tender evaluation, contract award, issuing variation orders, evaluation of claims, dissemination of information, certifying and making payments" (World Bank 2003a: 67, para. 150). Although the mentioned 'malpractices' need not automatically imply corruption, the information given by the interviewees indicate that corrupt practices do indeed feature in virtually every step of the procurement process.

One consulting engineer stated that corruption in the construction industry had reached "saturation point": hardly a step in the tender could be undertaken without involving some corrupt practice, and hardly a party of the construction project is untainted by corruption. As one architect exclaimed exasperated, "it is impossible to resist the client's

complications, the systematic expansion of the initial quotes points to embezzlement and misappropriation. 
corruption", meaning that the pressure from public officials on professionals to 'deliver' a cut from the project was as good as impossible to evade, given the fact that current and future income depends largely on being 'cooperative' with public sector officials. Saliently, this only seemed to apply to parastatal or government projects; all interviewees stated that corruption was inexistent when dealing with private clients. However, given the small volume of private clients and the overall dominance of construction in the public sector, at the time this was a merely academic point from the perspective of professionals. However, it did raise an interesting question when related to the ongoing process of deregulation and privatisation of formerly public services. The anecdotal evidence available seems to suggest that the abolishment of the parastatals did indeed lead to a substantial decrease in corruption and concomitant increase in efficiency and quality. ${ }^{48}$

Articulations on corruption by the professionals were imbued with a sense of loss of professionalism and integrity, outlined with various degrees of agitation. This loss was emphasised with references to its damaging effect on the public interest in terms of wasted or misappropriated public resources, with project costs systematically inflated or else the quality of work and inputs undercut. Project designs based on maximising corrupt profits evidently have serious repercussions on the quality of public construction: the structure of public buildings may not be adequately calculated, thus constituting a serious hazard to public security; the thickness of tarmac coverage on roads may only be a lower quality or only a percentage of the stipulated thickness; the materials utilised for public buildings are of poor quality; the fixtures and fittings do not adhere to required standards, or the quality of the cement suffers, etc. Examples abound of failures of public service, including negligent or even deliberate endangering of public safety - a problem particularly salient when it comes to the construction of public buildings, such as hospitals or schools, or key infrastructure, such as bridges. The deterioration of infrastructure such as roads due to technical 'short cuts' as a result of corruption have a more creeping but not less costly effect. ${ }^{49}$

48 Although this observance is encouraging, the fact that parastatals were quagmires of inefficiency, discretion and embezzlement shows that even a slight increase in transparency and accountability would have a noticeable impact. Also, the concomitant privatisation of key companies produced many opportunities for corrruption (for evidence see Chachage 1996, Temu/Due 2000, or Fischer 2006).

49 The information in this section is based on the interviews with professionals and experts. It is consistent with findings from more general studies on corruption in the 
According to some interviewees, the nineties also saw a plethora of "bogus contractors" [sic], whose only purpose was to access lucrative public tenders, mostly in collusion with public officials. Although this practice had been curtailed by the privatisation and deregulation of parastatals as well as the more stringent regulatory framework, the public procurement process was still rife with abuse and manipulation, if possibly in more subtle forms. As the literature on corruption in public procurement shows and the professionals confirmed, corrupt practices in construction are notoriously difficult to monitor, especially given the kind of complex and technical calculations involved in construction projects. ${ }^{50}$ These include project costs that are inflated by unnecessary or overpriced expenditures, or ballooning of the quantity and measurements of certain inputs. Several informants assured me that cases of even grossly inflated project costs were not isolated incidents: according to most interviewed professionals, there is virtually no road construction in Tanzania which was not systematically overpriced. The same applied to building projects of parastatals and state institutions. ${ }^{51}$ These problems were exacerbated by the fact that although the procurement procedures have been standardised under the PPA, at least on a national level, there was still no proper technical auditing or monitoring of final project costs, which made the 'adjustment' of projects costs a sitting duck. ${ }^{52}$

construction industry, such as Kenny 2007, Ware et al. 2007, or Goldie-Scot 2008. Further examples of corrupt practices were given by the professionals in abundance. For instance, before the Public Procurement Act was passed, collusion between public officials and bogus 'brief-case' professionals were apparently the rule, with all the ensuing severe problems of quality and security of work. Now it seems that the Public Procurement Act has indeed weeded out sham professionals, but not the pressure to corrupt: if you as an architect or constructor or quantity surveyor have to bribe, you cut corners somewhere else (see also below).

50 Just to illustrate the extent of these cost inflations, an architect described one current case of a big project commissioned by a parastatal, saliently with an explicitly social objective, where the overall costs were swollen from the necessary USD 5-10 million to a sum nearer USD 60 million. Looking at the scandals that have been uncovered since 2003 (for instance the Twin Tower case of the Bank of Tanzania involving corruptly inflated construction costs of USD 352 million which, according to experts, are about double the figure they would cost in London or Tokyo; see http://www.bongotz.com/news.html; last accessed 20 April 2010), the figures given by the architect seem very plausible.

51 At this point of the research, the impact of the legislative and regulatory reforms, for instance the newly established Tanzania Building Agency, could not yet be assessed, as they were still very new.

52 The problems relating to inadequate or inexistent auditing of project costs diagnosed by the interviewees were confirmed ex post by the Implementation Plan of the CIP. Under objective 8.2.8. 'Promoting the Prevention of Corruption in the Industry' a policy direction is listed as follows: "Instituting mandatory technical auditing of all major 
There are, however, further, less explored effects of the practical effects of corruption on the discursive space of professionals that emerged clearly from the interviews. These have only indirect implications for public welfare, but direct impacts on the sense of professional integrity and identity on the one hand and the economic conditions of professionals on the other.

\section{2. 'We survive through corruption, and we perish through corruption': Perspectives of Professional Associations}

Although there was no consent emerging from the interviews with regard to the extent of the effects of the governance reforms is debated, they had led to some degree of improved quality of tendering and public procurement. "You can't just buy work anymore", an engineer assured me, "you get more value for money". 53 At first sight, this could imply a strengthened governance framework for professionals working in the construction industry, and hence greater protection and predictability of their economic spaces. However, at second sight the situation looked far more sketchy.

The public sector was the biggest client of the construction industry, both in terms of the absolute numbers of tenders as well as of relative financial volume. Professionals had no sustainable economic alternative than gaining access to and being awarded publicly financed projects. Architects, engineers or contractors were all "hungry for jobs", as several interviewees confirmed in the very same words. According to the interviewees, public officials from the lowest to the highest level were keenly aware of the discretionary power they wielded. "The tender officers take all bribes [from all the parties submitting the tender, LK] and award the tender to the highest bidder", an architect complained. The bribes were evidently demanded on every echelon of the civil service, from the small public official, who will only hand out the tender documents against an additional fee, to the Minister, who has a certain standard of living to maintain. The bribes or percentages were usually either common knowledge, or directly disclosed to the parties in question. In other words, in some cases the level of corrupt 'commission' seem to be predictable, and other cases the amount was up to the discretion of the involved public officials.

pubic-financed projects and any other projects where there shall be suspicion of malpractice" (MID 2006: 56).

53 Although he also pointed out that in spite of the reforms of the PPA, there is no monitoring of the final project costs, which is an open invitation to inflate project costsnot for the tender, where cost-effectiveness is stipulated as a key criterion, but after the tender has been awarded. 
Such endemic corrupt practices, i.e. a situation in which personal enrichment through public resources in or beyond the grey zone between legality and illegality is the norm, not the exception, is not necessarily problematic. A 'corrupt' practice is a social practice like any other, framed by own, particular logics. These need not necessarily constrain the articulatory space of professionals, on the contrary. As the literature review on corruption shows, such practices conceivably can and do open up spaces of political, economic and social agency. Applied to the situation that the professionals in the construction industry found themselves in, one could argue that as long as they can materialise their professional activities through the acquisition of tenders and projects there is no apparent reason why they should oppose such practices. This is what one constructor meant when he remarked, "corruption is a higher way of competition". Detached from a moral judgement, in an essentially capitalist rationale, corruption is just part and parcel of doing business, just like 'ordinary' costing, at which some entrepreneurs are more skilful and successful than others.

Dwelling for a moment on this line of thought, the responses to the interviews indicated that undoubtedly some entrepreneurs gain from these corrupt networks and transactions. However, it was equally clear that even established professionals were struggling under the financial burden and the level of obstruction put forward by corrupt public officials. "The majority of companies suffer financial losses through corruption, they have nothing to gain from bribing", an established engineer underlined. The main problem facing professionals was that corruption cuts directly into their already meagre profit margin and threatens their economic survival. Put dramatically, it was a matter of survival. The dilemma was summed up in the words of an experienced and successful constructor and consultant: "We survive through corruption, and we perish through corruption". With every corrupt transaction professionals undertake they were actually undermining their own livelihood-not to mention their professional standards. In this way professionals in the construction industry were continually caught between a rock and a hard place, forced to weigh the financial cost of a bribe against the opportunity costs of an unawarded tender. According to an architect, the bottom line was very simple: "uncooperative" [sic] professionals are not awarded tenders; "our survival is at stake, which the clients abuse". ${ }^{54}$ Although all professional associations and their members were pressing for the respect

54 For a more general discussion of this dilemma see Koechlin 2007. 
and acknowledgement of professional standards, the individual entrepreneurs felt trapped in an economic bind. The situation was rendered more impossible by the fact that bribes or other corrupt deals did not necessarily increase the chances of being awarded the tender. Looked at this way, corruption is indeed a higher form of competition, but with a darker twist: corruption does not facilitate business transaction, on the contrary. Paradoxically, it actually increases the unpredictability of doing business rather than decreasing it.

There was an additional powerful economic factor squeezing the profit margins of the professionals, and that was the increase of competition. Whereas up to the late eighties and early nineties there had been only very few, small local companies and some big foreign companies, in the late nineties there was a massive increase of registered local engineers and constructors as well a substantial growth of foreign companies, especially from the East. ${ }^{55}$ The foreign companies are mostly involved in specific donor-funded projects from their home countries (which was standardpractice and constitutes a serious problem in itself), ${ }^{56}$ but increasingly they were taking part in the official tenders of all sizes at highly competitive rates. One consulting engineer estimated that just due to the influx of Chinese contractors the prices in construction had gone down by about one third. So although the situation for local contractors had improved in one regard, as the budget allocation to public procurement in construction had been significantly increased in the last decade, with a concomitant increase in tenders and projects and hence job opportunities, the growth of the local competition as well as greater foreign competition stepped up the pressure on professionals.

55 According to estimates from the ERB, foreign companies only constitute about $3 \%$ of all companies and undertake about $80 \%$ of the work; which leaves the remaining $97 \%$, all very small to at best medium sized companies to compete for the $20 \%$ of the work. Mostly, domestic companies work as sub-contractors to foreign companies.

56 This is evidently a big problem for the local construction industry, namely that their marginalisation as to know-how and experience is in fact systematically entrenched by implicitly or explicitly excluding them from foreign funded projects. This has partly a functional explanation: most construction firms do not have the capacity or the expertise to do large-scale, technically demanding projects. But even here local participation, e.g. by breaking bids into smaller, more manageable projects, is "a very thorny issue", as a chairman of a consultants' association cryptically remarked. Donors seem to routinely favour their home industry, and the government seems to be still caught in a bias against the local industry - an aspect which would merit more systematic attention. The CIP addresses the problem by identifying "inappropriate contract packaging of works which favour foreign firms in donor-funded projects" and "[u]nfavourable donor conditionalities which tend to marginalize local construction enterprises” (MID 2003: 7). 
Notably, governance reforms can also have unintended consequences. Paradoxically, in one way they rendered the professionals even more vulnerable. In spite of the flaws of the new procurement procedures it had become increasingly difficult for the professionals to randomly inflate project costs. To 'deliver' the demanded (often shameless) bribes to public officials, they now had to dip into their own pockets. In many cases they could simply not afford to do this. ${ }^{57}$ The gist of the interviews, whether with tiny one-man-enterprises or with representatives of established, relatively large firms of twenty or more employees, was that the financial pressure exerted through corrupt demands of the civil servants was strangling. This additional financial pressure posed particularly serious problems for the micro- and small enterprises; they did not get the chance of accumulating any profit without it being pocketed by some official, and they were rendered even more vulnerable by the fact that their industry was characterised by the lack of supportive institutional mechanisms, such as financial credit facilities or other collaterals to draw upon, by unfavourable tax regimes, unfavourable working environment with regard to salaries, safety or health, and erratic work-opportunities. ${ }^{58}$

It comes as no surprise, then, that professional associations were key to problematizing corruption in the construction industry in public, by linking the problem of corruption to the problems of infrastructure development, public welfare and official government policies. In particular, it seems that one workshop constituted a crystallisation point, the Workshop on Corruption Prevention, organised under the auspices of the Ministry of Works in March 2001. The workshop brought together all the main stakeholders of the construction industry. ${ }^{59}$ Professional associations evidently played a catalytic role in making this workshop happen. Several interviewees confirmed that was the first time the problem of corruption

57 The case of one contractor was reported where the official had demanded a bribe of USD 40,000 for the award of a particular project, although the bid of the entrepreneur in question had been the most competitive. Although the contractor was prepared to pay to get the award, he could only afford to offer USD 10,000. The result was that he was disqualified and the project was awarded to someone with greater financial liquidity than him. Even if he had been in a position to inflate the project costs to regain the costs of corruption, the lack of financial liquidity prevented him being awarded the contract in the first place.

58 These problems were emphasised by the interviewees from both the private and the public sector, and they are explicitly acknowledged in the CIP (see CIP 2003: 6, section 3.3. 'Performance Constraints').

59 See The United Republic of Tanzania 2001 for details on issues addressed and participants. 
in the construction industry had been openly addressed by all stakeholders, and underlined the way in which professional associations had articulated corruption in the public sphere and sought to inscribe their own interests and demands in the official discourse.

\section{3. 'They are blind and deaf': Perspectives on Public Officials}

The unanimous opinion of all respondents was that corruption in the construction industry is driven by the public sector. A representative of the Engineers Registration Board observed that "the problem is low prestige and low salaries of public officials. Both affects their integrity and their motivation. The combination of low living standards and a high status of wealthy people creates an environment that is conducive to demanding bribes". Indeed, the wage levels in the public sector were significantly lower than in the private sector. ${ }^{60}$ For a graduated engineer without much experience the ratio was estimated to be about 1: 4, with the discrepancy growing at every level. ${ }^{61}$ Looking at the costs of living, civil servants were under real pressure to seek for additional income, legally or otherwise. Most professionals displayed an astute sense of the economic restraints facing small public officials - which is not to say that they didn't suffer from the harassment and trouble caused by petty corruption. Still, there was palpable empathy for the pressure to be corrupt in the lower cadre, as a product of economic constraints. As an engineer replied, "the basic issue is subsistence", i.e. the subsistence of the public officials, some of whose wage-levels barely met everyday needs. The understanding of this was echoed in many different statements.

This discerning attitude may also have stemmed from the fact that most engineers and contractors were themselves former civil servants, not surprising given that the formalised private sector was a relatively new phenomenon in Tanzania. In many cases, the interviewed professionals had been in the same departments or positions as the ones harassing them.

60 For the construction industry in Tanzania, see for instance the CPAR (World Bank 2003a: 67, para. 151).

61 The figures quoted by different sources were the following: A graduated engineer without much experience would earn a monthly salary of about USD 100 in the Ministry of Works and about USD 400 in the private sector; an engineer with about 10-15 years experience the equivalent would be USD 150 in the Ministry and anything above USD 600 in the private sector. These figures are at best indicative; the Road Fund funds the salaries in the Ministry of Works, so engineers in the public sector probably earn more than their colleagues. This is also the reason why most public officials endorse in other commercial (not necessarily corrupt) activities during their work-time. 
However, the extent of their understanding was strictly qualified to serious economic distress, which only accounts for some corrupt practices. The professionals seriously criticised the rigorous, unbending, and often unprofessional (in the sense of unskilled and disinterested) attitude of the public officials. A graphic depiction of this was given by two representatives from a contractor's association, who described how they would plead with their former colleagues from the public sector, who were obstructing their business to elicit a bribe, to be less technocratic and more responsive to the interests and needs of the professionals, reminding them that one day they too might want to run their own business and would then be faced with the same difficulties; ${ }^{62}$ "but they are blind and deaf, they think they will remain in office indefinitely", the contractors concluded exasperated. The problem was official discretion, but it was coupled with a particular official attitude, an attitude showing scant regard for the different rationale governing the private sector, and disregarding the role of the administration as the warden of public interests. The normalised practices of the public officials seems to be informed by a mixture of selfserving and unprofessional attitude.

The general view taken of mid-to high-level public officials and the Ministers by the representatives of professional associations was far more uniform in its condemnation. "Greed!" was the unfailing and often bitter answer to the reasons fuelling high-level corruption. Their salaries, additional perks (such as cars, housing, staff, etc.) and privileged position were perceived to be more than sufficient; their corruptness as merely selfserving enrichment. In the opinion of the professionals, public officials were feathering their already soft nests at the expense of ordinary citizens and professionals struggling to make ends meet. In addition, public office in itself had become a socially legitimate avenue to gain wealth, irrespective of income levels. Corruption was now "a way of life", a "societal ill", because it was generally accepted attitude that public officials use their position to enrich themselves. ${ }^{63}$ Wealth in itself has become such a social goal that the means of acquiring it are irrelevant. "Riches are respected no matter what. If you have a nice position and leave it poor you were stupid not to make use of it!" exclaimed a frustrated senior engineer. His

62 As far as could be ascertained, the fact that the officials in question were acting illegally was not part of their argument-a telling omission.

63 The sentiments of the former Foreign Minister quoted above were confirmed (often verbatim) many times in the course of the interviews, by interviewees of all ages and backgrounds. 
colleague put it more strongly: "If you are poor, you are stupid. If you are not corruptible, you are stupid!" Hence, the fact that personal, short-term motivations drive public officials to corruption overshadowed the problem of inadequate remuneration; the remedy of the latter would be rather straightforward, the remedy of the former rather more intricate. ${ }^{64}$

The interviewed public officials themselves obviously did not dwell on their own corruptibility. They underlined other factors that the professionals also prioritised, namely the inadequate technical training and professional exposure of entrepreneurs, still cumbersome procedures, the time-lag in implementing the rapidly changing rules, and of course the reforms that have been achieved in a relatively short time. Some did lament the insufficient support from the government in protecting and developing the local construction industry, and the slow and juddering pace of designing and implementing a construction industry policy. When asked directly about corruption, the answers were either a reference to the existing anti-corruption clauses, for instance of the registration boards, or a very opaque response about the difficulties and challenges of public procurement.

\subsection{Professional Identities, Social Agents and Political Struggles}

Of course, professionals themselves were not immune to the prevailing primacy of profit-grabbing, be they engineers, architects or contractors. The interviewees themselves acknowledged this: "To grow you have to put everything back into your business, but this is not recognised here, there is a fast buck attitude". Cases of collusion and corrupt practices by entrepreneurs were mentioned throughout the interviews. But the interviewees from the private sector were all members or representatives of professional associations; they distinguished themselves within the community precisely through their engagement to improve and protect professional conduct, distinguished by integrity and quality. The overarching ideal articulated was that membership in a professional associations signifies the hallmark of professional quality, in the eyes of the professional community, in the eyes of the general public, and perhaps most importantly, in the eyes of the public sector and the government. Generally, the

64 In a critical analysis of the relationship between public officials pay and corruption in Tanzania, Mutahabe comes to the conclusion that "the link between pay and corruption is tenuous" (Mutahabe 2005: 1), confirming the doubts with regard to the degree of pay being a significant factor shaping the extent of corruption. 
majority of the professionals interviewed were deeply unhappy about the way corruption affected the standards of their work and their reputation as a sector.

Professionals in the established professions, such as consulting engineers or architects had an acute and internalised sense of professional conduct, reflected in their self-perception, in their reasoning against corruption, and, on a more formalised level, in the constitutions of their associations. ${ }^{65}$ The associations themselves were all established with the prime reason of increasing the quality of professional standards and lobbying to create a facilitative regulatory framework guaranteeing and supporting these standards. ${ }^{66}$ Routinely, all constitutions feature tailored Codes of Conduct. For instance, the Code of Professional and Ethical Conduct forms an integral part of the constitution of ACET, and is derived from international best practices. ${ }^{67}$ It includes provisions on professional integrity with regard to safe-guarding the public interest, in particular with regard to safety, health, property and welfare of the public (Art. I 1 and I 2); with regard to professional expertise and honesty (Art I 3 and I 4); an anti-bribery clause with regard to clients (Art I 5$)^{68}$ as well as suppliers (Art III 4);69 and a provision regulating conflict of interests (Art II 4). The codes of professional conduct are in substance very similar to the rather slicker ones

65 For instance, ACET is an active member of the apex organisation FIDIC. With leading participation of ACET, FIDIC developed a cutting-edge code and manual of Business Integrity Management Systems in 2002.

66 For a seminal historical contribution analysing the economic interests that drive the development of associations with their exclusionary professional standards and qualifications see Weber 1985: 203-209 in the chapter on "Gemeinschaftsformen und ökonomische Interessen".

67 In fact, Art I 7 of ACET's constitution explicitly refers to the standards of professional conduct laid down by FIDIC (Association of Consulting Engineers Tanzania (ACET). Code of Professional and Ethical Conduct. In: ACET (1985). Constitution (fourth edition 2008). P. 35).

68 "No Member shall offer, give, solicit or receive, either directly or indirectly, any political contribution in an amount intended to influence the award of a contract by public authority, or which may be reasonably construed by the public of having the effect or intent to influence the contract. He shall not offer any gift or other valuable consideration nor pay a commission or percentage in order to secure work" (Association of Consulting Engineers Tanzania (ACET). Code of Professional and Ethical Conduct, Article I 5. In: ACET (1985). Constitution (fourth edition 2008). P. 35).

69 "No Member shall solicit or accept gratuities, directly or indirectly from contractors, manufacturers or suppliers, his agents or other parties dealing with his clients or employers in connection with work for which he is responsible" (Association of Consulting Engineers Tanzania (ACET). Code of Professional and Ethical Conduct, Article III 4. In: ACET (1985). Constitution (fourth edition 2008). P. 37). 
stipulated in the Constitution of the Institute of Engineers (IET) ${ }^{70}$ relating to: Conduct of members; Conduct of corporate members; Duty to uphold professional reputation; Duty not to indulge in corrupt practices; ${ }^{71}$ Duty to serve the interest of the client; Malicious damage to professional reputation; Continuing professional development; Penalty for breach of conduct. Remarkable in both cases is the emphasis on professional reputation and the respect for professional conduct.

All associations have the authority to discipline or, in severe cases, exclude members in cases of professional misconduct. ${ }^{72}$ However, at the time of the interviews, the associations were diffident in actually endorsing these measures. There was a tangible preference of all representatives to address cases of misconduct more informally, through peer pressure, rather than enact a formal disciplinary procedure. The reasons given were persuasive: the associations had relatively few members, drawn from a professional community that was very small and characterised by face-to-face interactions, not by impersonal procedures. Although formal disciplinary had been employed in cases of severe misconduct, in the first instance personal, direct interaction (albeit in the formal roles of Council member or chairman, and member of the association) fitted more closely to established practices and features of the community. In cases of corruption, a second layer seemed to be added: as corruption was an endemic element of virtually all transactions within the construction industry, professional associations were realistically not in a position to discipline their members. Such sanctions would have backfired on the associations themselves, as they risked either ridicule or disengagement. As associations they are committed to protect the interests of their members, and the interviews revealed a strong sense that the structural pressure to corrupt could not be resisted by disciplining individual members. In addition, in the view of the associations and professionals there were no credible accountability

70 See Section 8 'Professional Conduct', subsections 8.01-8.08. In: The Institution of Engineers Tanzania (1975, revised 2007). The Constitution. pp. 15-16.

71 "A member of the Institution shall not indulge in any corrupt practices", in: The Institution of Engineers Tanzania (1975, revised 2007). The Constitution, Section 8.04., p. 15.

72 See for instance the Constitution of the IET: "Any alleged breach of Sub-sections 8.01 to 8.07 which may be brought before the Council, properly vouched for and supported by sufficient evidence, shall be dealt with by the Council either by expulsion of the offender from the Institution under the procedure in Sub-section 7.03 as far as it applies, or in such a manner as the Council may think fit" (see Section 8.08 in: The Institution of Engineers Tanzania (1975, revised 2007). The Constitution. p. 16; or the Disciplinary Proceedings stipulated in the Constitution of ACET (ACET (1985). Constitution (fourth edition 2008). Disciplinary Procedure. pp. 39-41). 
institutions that would reinforce such community-internal sanctions. "There is no trust", sighed an exasperated engineer: existing institutions, such as the Public Procurement Appeals Commission, the Registration Boards, the PCB, or even the judiciary were not trusted sufficiently to act as safeguards of integrity. Not one of the interviewees, from the public or private sector, could give a straightforward, unambiguous response to examples of complaints processes that had been taken to one of the public accountability agencies. The one case of corruption mentioned that was taken up by the CRB with involved a foreign company, who subsequently withdrew their tender.

Still, what emerged from the interviews is that professional standards had definitely 'hardened' and improved in the past decade, due to (a) the self-regulatory initiatives and the advocacy efforts of the professional associations, (b) the institutional and regulatory reforms such as the establishment of registration boards, and (c) better availability of trainings and continual education. Professional associations played an important role in providing such trainings on behalf of or in cooperation with the public sector (and sometimes donors), drawing on their own expertise as well as the expertise provided through their affiliation with international associations. More tangibly, with the establishment of the registration boards professional standards were now formally acknowledged,- - a hard-earned victory by professional associations.

At this point, a distinction needs to be drawn between professional identities of first generation associations on the one hand and professional identities of second generation associations on the other. As elaborated above, 'established' professions conveyed the impression of being comfortable and secure in their professional identity, drawing on and referring to established domestic, regional and international networks and standards. The situation with regard to contractors, however, was rather different. Local contractors only had a very recent history of professional identity, as was also reflected in the recent establishment of the only two contractors associations. It was a young profession, tainted by a low social status and with a reputation for badly executed work and unskilled and profitgrabbing contractors. Both contractors associations were established with the explicit intention to fight against such non-professionalism, i.e. to change the 'bad attitudes' and malpractices within the profession; to define and institutionalise professional standards; to improve their negative image in the public, and, lastly, to support a better industrial framework and working conditions of contractors. 
Both in public and in the course of the interviews, the contractors were far more outspoken than the first-generation associations, articulating their interests in a significantly more confrontational way. For instance, when the Contractors Association of Tanzania (CATA) was formed in 2003, their chairperson, engineer Consulata Ngimbwa, explained in a newspaper interview that one of their key motivations is to enhance the public and government recognition of the profession. She goes on to underline the importance of the regulatory framework:

Half of the government budget goes to construction. But the public perceives local contractors as incompetent and dishonest. The few projects awarded to them have been unduly delayed, or executed shoddily and in some extreme cases, abandoned. The problem here is not incompetence but the environment under which they get these works, the rules are not good. ${ }^{73}$

The quote is very revealing, connecting the contractor's negative image with the structural problems of the country-with a terse reference to the paucity of work available to local contractors - and thus linking up the (official) rules framing contractors' work with their reputation. This statement can be interpreted as a very direct demand for a better legislative and regulatory framework. However, it also includes a thinly veiled reference to the common knowledge of public officials' corrupt behaviour.

All in all, both first and second generation professional associations in the construction industry of Tanzania were central to the development of a regulatory framework and professional standard-setting, and to the public articulation of the importance of professionalism with regard to public welfare and cost-effective use of public resources. Equally, they were seminal in pushing for governance reforms that improve the economic basis of their profession, including more predictable and coherent norms that protect professional qualifications and conduct. Bringing in professional expertise and international networks and exposure, they engaged in dialogue and coalitions with relevant actors of the public sector, seeking to influence and improve (if with uneven success) the design and implementation of governance reforms, and strengthening their own professional position. In 2003, the governance reforms were gradually being consolidated and merging into a recognisable, comprehensive regulatory body, with the key pillars being the registration boards, the CIP and the PPA.

73 See "Contractors' body to press for law review", Daily News, 24 February 2003, p. 5. 
However, a perhaps perverse effect of the success of governance reforms - the establishment of a registration board — was already discernible, if only from the perspective of an established first-generation association, namely ACET. A long-standing, internationally renowned and distinguished member made the rather shocking comment that "the Engineers Registration Board destroyed ACET". What he meant was that up to about the year 2000, membership in ACET, which is conditional on specific professional qualifications and standards, constituted a hallmark of excellence. Around the year 2000, the ERB took over the statutory registration of companies. The statutory requirements of the ERB obviously override the criteria stipulated by ACET, so membership in ACET constituted no real professional distinction anymore. In other words, official regulation, although welcome from a perspective of general and formalised rules, encroached on self-regulatory achievements. It also constituted greater state control over professionals - the power to register as well deregister them - that in the absence of the rule of law and independent and effective horizontal accountability bodies had ambivalent effects. ${ }^{74}$ Furthermore, although this was not mentioned here, against the backdrop of the increasingly authoritarian tendencies and penchant for 'social compacts' within the administration, it is conceivable that the registration boards actually facilitated the governmental appropriation of autonomous representations and counterveiling interests. ${ }^{75}$

The sudden irrelevance of a central function and constituting element of ACET was compounded by the development within the professional community itself. ACET represents the interests of consulting engineers. However, according to this respondent, the increasing technical focus of the engineers - itself also a feature of the increasing professionalization of the industry-lead to a situation in which most members of mid-level management of the companies lost interest in business development or

74 For an interdisciplinary analysis and case-studies on shifting boundaries of normative authority between public and non-state actors see the volume edited by Peters/Koechlin/Förster/Zinkernagel Fenner (eds.) 2009.

75 According to the provisions of the ERB, the Minister of Works appoints the Board. The provisions specifically require that the two of its nine board member are not in the service of government; these two board members have to be nominated by ACET (one) and IET (one) (!) (see http://www.erb.go.tz/composition.htm; last accessed 25 March 2010). The statutory inclusion of professional associations in regulatory bodies can be an indication of their official recognition, but it can also be seen as a form of cooptation (for a discussion on risks and strengths of such multi-stakeholder fora see Koechlin/Calland 20o9; for a critical view on governmental co-option strategies of civil society organisations by African governments see Bratton 1989). 
industry politics. Although this could not be verified, it might also be an indication of short-termism of professionals. In any case, it manifested itself in a loss of membership. The decreasing membership lead to a decrease in representativeness and voice of the associations. The problem of insufficient membership was mentioned by all representatives of all associations. Be it that the professionals "don't recognise the benefits of collective action" (diagnosed by an architect) or that the professional associations "do not identify the burning issues" (diagnosed by a consulting engineer with regard to the established first-generation associations), the conclusion was clear: "They [i.e. professional associations] are weak", as several informants across the professions observed. And in a full vicious circle, the decreasing membership threatened both the financial basis of the professional associations, which are dependent on voluntary work and membership fees, as well as weakened the voice of the professional associations vis-à-vis the public sector.

\section{Hegemonies and Fixations of Corruption: Some Preliminary Conclusions}

Summing up, the engagement of first as well as second generation professional associations was primarily aimed at creating a level playing field and defining professional standards. But although the associations were actively engaged in policy discourses, the collective and individual actors were seriously struggling with more basic issues, in particular structural problems, such as the dependence on the public sector and the crushing competition of foreign competitors and inaccessibility of resources (funds, equipment, collaterals, technology, experience). Hence, corruption was routinely and often vocally recognised to be a serious problem, but under the difficult economic and political circumstances which rendered the implementation and internalisation of professional standards near impossible, it was always set in the wider governance context of inadequate public institutions and industry policies. Professional associations observed that the prevention of corruption was in their own core interest, as they had a driving economic, political and professional need to increase the predictability and security of their situation. In addition, they had an ideological interest in articulating standards of professionalism and relating them to their particular profession, formalising distinctions between themselves from other groups within the same profession (e.g. civil contractors v electrical contractors) or within the same sector 
(e.g. architects v engineers). These distinctions were pivotal to the construction of differential identities for official recognition and public acknowledgement. In this way, they appropriated and sought to shape the language of governance and anti-corruption reforms, articulating their own particular interests (such as salary scales, credit facilities, protection from foreign competition, etc.), and constructing linkages to their particular discourse to wider discourses, such as the rule of law, state effectiveness, public service and national development.

It can be concluded that 'corruption' thus works in a double bind:

On the one hand, corruption was indeed an empty signifier in the most political sense, framing the most significant nodal points through which linkages across the public-private divide and more generally across differential identities took place. 'Corruption', as could be observed, was filled with particular demands and claims, but as an overarching reference point provided the terrain of political struggles around contentious identities, interests, and representations. As perhaps was to be expected, the fissures and antagonisms of these differential articulations were far more subtle than just between public/private, or integrity/greed, or professional competence/incompetence. They ran between and across the spheres, they ran within professional communities, and they ran across social imaginaries. ${ }^{76}$ They were not arbitrary, however. Corruption constituted a powerful signifier, publicly relating immediate needs, interests and constraints of professionals to a wider horizon. Thus, nascently and unevenly, professional associations successfully filled 'corruption' to signify not only professional standards, qualifications and expertise, but also to link it to discourses of governance and development. In this sense, professional associations opened up emancipatory spaces that enabled greater and more diverse forms of articulation.

On the other hand, corruption was also a medium undermining the discursive resources available to professional associations. Quotes in the sense of 'Corruption is a higher form of competition', or 'If you are poor, if you are not corruptible, you are stupid', point to a rather different significance of corruption. This discourse was less manifest in its articulations in the public sphere, but all the more dominant in economic transactions. From

76 To illustrate this point with an example, justifications for the importance of professional conduct and integrity was given by the respondents in reference to the requirements of the market economy (competitiveness) as well is in reference to the socialist values formulated under Julius Nyerere. 
the reflections of the professional associations' realities, the dominance of this discourse was felt astutely. This discourse forged chains of equivalence around non-legal, rhizome nodal points, such as the general acceptance of enrichment through bureaucratic means (which does not equal the professionals' understanding of entrepreneurial and legally acquired profit), of personal contacts, of the (ab)use of power differentials - understood and known by everyone, but not articulated in the public realm.

But the perhaps most unexpected finding is that the governance reforms, for all intents and purposes strengthening the corruption discourse of the professional associations, were antagonistic in their effects. In line with the intended and formalised objectives, they reaffirmed demands for greater predictability, for rule-based processes, for safeguarding professional quality-largely echoing the articulations of the professionals grouped around and within 'corruption'. But at the same time the 'official' discourse on corruption deflated the professionals' discourse on corruption by hegemonising their representations and appropriating the nodal points-registration, accreditation, definition of norms and standards. This happened largely on a symbolic level; the practical effects-such as the transformation of 'official' identities, or the internalisation of formal norms - remained incremental. However, assessing the very diverse fixations of corruption in the construction industry of Tanzania, one component cannot be stressed enough: the demands, values and indeed interests were very young. They were in flux, within a rapidly changing frame of reference-economically, politically, socially-and the observed processes and actors emergent, fragile and unstable.

However, as a preliminary conclusion, the power relations were still characterised by significant differentials between (and in fact: within) the public sector and professional associations. Professional associations managed to successfully employ corruption as an empty signifier, connecting it up to wider corruption discourses of development agencies as well to governmental discourses. Generalising across the differences of successful professional articulations, the identities of the professional associations was strengthened through these successful partial fixations, separating, at least on a formal level, the 'professional' from the 'unprofessional'. The price is paradoxically a partial loss of identity, a collapse of a sense of purpose, which was hegemonised by governmental regulatory bodies.

Corruption as an empty signifier is thus a brittle bearer of professional articulations and interests. From the snap shot of this case-study, the future flow and patterning of the discourses cannot be predicted with more certainty than at the beginning of the study, albeit the struggles can be made 
out in more detail. The findings do outline two main currents: In time, the hegemonic representations of professional associations around meanings of corruption may well link up to a critical mass of nodal points, feeding into swelling discourses on democracy, on economic development, and be transformed into public and secure spaces of economic, political and social agency. By the same token, professional identities, far from being profiled and differentiated and 'universalised', may well be hegemonised and smothered by other discourses on corruption, closing down the practical and symbolic spaces of professional associations to a narrow strip of technicalities. 